\title{
НАУКОВО-ТЕОРЕТИЧНІ АСПЕКТИ ОНІРИЧНОЇ ПАРАДИГМИ В ІНТЕРДИСЦИПЛІНАРНОМУ ВИМІРІ
}

Газуда О. М.

\section{ВСТУП}

Концептуальною основою оніричності $€$ узагальнене ідейноестетичне спрямування творчих досягнень і надбань певного автора. У літературознавстві до оніричного підходу майстри художнього слова звертаються в тому випадку, коли вони прагнуть відтворити в художніх світомоделях сутність або ж властивість складних явищ і процесів у вирі суспільних подій, адже реальність не завжди можна повноцінно охопити, сприйняти й усвідомити 3 огляду на її відповідність окремим принципам інтелектуального мислення, логічного підходу, що, у свою чергу, відрізняється від тілесного аспекту й емоційно-чуттєвої сфери. Отже, за допомогою оніричних підходів письменники обгрунтовують узагальнені закони буття, розглядаючи їх крізь призму власної індивідуальності й авторського бачення.

У літературознавстві в основі позитивізму лежить парадигмально гносео-методологічний підхід, за допомогою якого вивчаються загальні передумови пізнання, що є вищою формою відтворення об'єктивної реальності, досліджуються явища та процеси життєвого простору людини, тобто відбувається конкретно-наукове пізнання. Інтерпретаційна парадигма як певний діяльнісний складник творчого процесу, поєднує трактування змістового наповнення літературного твору 3 окремими сукупностями й літературною цілісністю вищого порядку, наприклад творчості письменника, літературної школи чи літературного напряму загалом. Розгляд парадигми літературного твору крізь призму функціональності базується на сукупності властивостей, здатних формувати упорядковану цілісність літературного тексту в певному сюжетному середовищі.

У процесі літературознавчої розвідки, у тому числі детального вивчення твору через художні образи й оніричні елементи на рівні особливої форми світоглядного бачення людини, за якої зберігається іiї предметно-чуттєвий характер і цілісність внутрішнього світу, найбільш прийнятними до застосування, на нашу думку, $є$ змістові позиції трактування парадигми як а) фундаментального набору припущень, що визнаються й сприймаються науковим товариством у спільній практиці 
(R. Hirschheim, H. Klein) ${ }^{1}$; б) окреслення проблемного процесу дослідження парадигми, який охоплює проблеми розуміння та проблеми вирішення (A. Hevner, S. March, J. Park, S. Ram, G. Smith) ${ }^{2}$. Саме вони стосуються особливого формату наукових досліджень шляхом критеріального оцінювання авторської мисленнєвої думки, утіленої в художні образи твору, 3 подальшою інтерпретацією результатів дослідження й теоретичних підходів або ж певної моделі постановки проблеми.

\section{1. Теоретичні підходи до тлумачення сутності оніричної парадигми}

Узагальнення літературних розвідок дає підстави стверджувати про існування багатогранності тлумачень понять «оніричне» й «онірична парадигма». Формування відповідних літературних підходів до трактування досліджуваної проблематики здійснили, зокрема, такі літературознавці, як Н. Андрейчук, Д. Балтімор, Ф. Бацевич, Г. Бергман, Дж. Гордон, Р. ДіЯнні, А. Зарайський, С. Кримський, Т. Кун та ін.

Творчий, індивідуальний підхід, що застосовується в процесі виокремлення оніричних елементів, формує стиль викладу художнього твору. Цей стиль, як аргументовано підкреслив М. Гіршман, є «своїм іншим» стосовно поняття «автор» $\mathrm{i}$ може бути визначеним як a) найбільш безпосереднє, видиме й відчутне вираження авторської присутності в кожному елементі твору, б) як матеріально втілений i творчо відчутний слід авторської активності, що створює й організовує художнє ціле ${ }^{3}$. При цьому автор акцентує увагу саме на індивідуальному. Звідси виникає необхідність модифікації закономірностей формування оніропростору в прояві творчої індивідуальності митця.

Через призму власної індивідуальності й незалежного творчого бачення митець формує набір оніричних елементів і парадигм на рівні сукупності понять та уявлень, властивих певному оніричному простору, використовуючи авторський стиль викладу художнього матеріалу. Зазначений підхід застосовано в студії «Література: читання художніх творів, поезії, драми та есе» Р. ДіЯнні. Дослідник наголошує на тому, що «спосіб, яким автор обирає слова, складає їх у речення,

${ }^{1}$ Hirschheim R., Klein H.K. Four Paradigms of Information Systems Development. Communications of the ACM. 1989. № 32. P. 1199-1216.

${ }^{2}$ Hevner A.R., March S.T., Park J., Ram S. Design Science in Information Systems Research. MIS Quarterly. 2004. № 28. P. 75-105; March S.T., Smith G.F. Design and Natural Science Research on Information Technology. Decision Support Systems. 1995. № 15. Р. 251-266.

${ }^{3}$ Гиршман М.М. Литературное произведение: теория и практика анализа : учебное пособие. Москва : Висш. шк., 1991. С. 75. 
а потім у частини дискурсу, використовує ї важливість і визначає стиль. Стиль - це словесна індивідуальність письменника, очевидне, як його лице чи голос. Відображаючи свою індивідуальність, авторський стиль передає його особливий спосіб бачення світу» ${ }^{4}$. Цей вислів підтверджується в дослідженнях Дж. Гордона, де він апелює до міркування Дж. Свіфта, що «правильні слова на правильних місцях і роблять точне визначення стилю» ${ }^{5}$. Саме Дж. Гордон зазначає, що ті, хто погоджується 3 такою точкою зору, аналізуючи твір, спочатку розбивають його на частини й лише згодом аналізують.

Отже, будь-який митець має власні творчі уподобання, уявлення й незалежне бачення, володіє самобутнім світоглядом. Усе це дає можливість тому чи іншому автору створювати й формувати систему оніричних елементів. Акцент покладено на взаємозумовленості й взаємозалежності образів сну та сновидіння, що характеризує унікальний авторський індивідуальний підхід. Сприйняття чи несприйняття реципієнтом пропонованого автором художнього образу відбувається через майстерне поєднання й презентування оніричних елементів, які мають як вірогідний і ймовірний, так і достеменний, або ж правдивий, підтекст. Однак зазначений підтекст тісно переплітається й корелюється залежно від явищ і процесів, між якими не існує чіткого взаємозв'язку, а отже, і не відчувається функціональна виразність.

Процес дослідження оніричних підходів у літературознавстві тісно переплітається із сутнісними особливостями поняття парадигми, яке трактується багатоаспектно в різних наукових напрямах. Так,

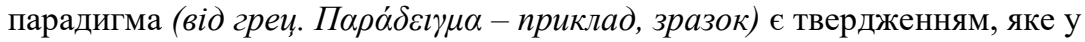
філософському розумінні взаємозумовлюється духовним і реальним світосприйняттям, тобто загальним світобаченням, яке часто використовується в інтердисциплінарному вимірі, зокрема в напрямі дослідження художнього оніропростору.

Структурне розчленування поняття парадигма стосується передусім першого складу $\pi \alpha \rho \alpha-\delta \varepsilon i ́ \chi v v \mu 1:$ префікс $\pi \alpha \rho \alpha$ зі значенням близького, суміжного розташування та доповненням розуміння терміна, а саме показувати, зіставляти, представляти. В. Дем'янков відмічає, що навіть у старогрецькій мові слово вживалося в кількох значеннях, які взаємозумовлювалися спільною семою, тобто з єдиною смисловою одиницею як граничною, неділимою складовою частиною лексичного значення (семами). В основі обгрунтування відмічених значень $є$ певна

${ }^{4}$ DIYanni R. Literature: Reading Fiction, Poetry, Drama, and the Essay. $4^{\text {th }}$ ed. McGraw-Hill, 1998. P. 86.

${ }^{5}$ Gordon J.B., Kuehner K. Fiction: the Elements of the Short Story. McGraw-Hill Glencoe, 2000. P. 243. 
спільність, що проявляється в «орієнтації на зразок», а саме: по-перше, як зразок, модель; по-друге, як приклад; по-третє, як наочне підтвердження, доказ; по-четверте як повчальний приклад, урок; nо-n'яте, як подоба, зображення ${ }^{6}$.

Докорінна основоположність присутня при розгляді парадигми через призму радикальної гуманістичності, що у сфері літератури відіграє вагому роль, оскільки взаємозумовлюється гуманістичним (людяним) світоглядом, де особливого значення набуває людина як індивідуум та особистість, а також ставлення, турбота про іiі благополуччя, добробут i повагу до неї. Парадигма радикальної структурологічності художнього твору формує цілісність його побудови, водночас дає можливість розглянути художній текст поелементно і прослідкувати взаємозв'язок між цими елементами.

У філософському трактуванні поняття «парадигма» обгрунтовується як сфера вічних ідей, первинний образ, зразок, за яким створюється світ буття. В англомовній літературі досліджуваний термін уживається ще 3 XV ст., також у контексті певного зразку або ж моделі. Упродовж останніх чотирьох століть парадигма слугує для позначення граматичних форм одного слова чи граматичних категорій частини мови. До речі, у словнику Merriam-Webster (1900р.) сутнісне пояснення парадигми подано лише в контексті лінгвістики та риторики (ілюстративна оповідь чи казка). У лінгвістиці тексту як галузі мовознавства, де досліджуються структурно-граматичні, семантикозмістові, комунікативно-прагматичні, семіотичні властивості тексту, його категорійні ознаки, закономірності структурної організації, зв'язки з іншими текстами, а також процеси створення, сприймання й інтерпретації, у тому числі й художнього тексту, тлумачення парадигми зумовлюється типом зв'язків у мовній системі, які встановлюються на підставі варіативності, подібності, протилежності, похідності, включення, субкатегоризації мовних одиниць та унеможливлюють їх одночасне уживання в певній позиції. Парадигма кваліфікується як відношення підпорядковані логічній диз'юнкції (або/або) ${ }^{7}$. При цьому риторика в літературознавчій розвідці парадигми, як, зокрема, і оніричної парадигми, розглядається крізь призму внутрішньотекстових відносин, соціальної функціональності тексту,

6 Демьянков В.3. Парадигма в лингвистике и теории языка. Горизонты современной лингвистики: Традиции и новаторство : сборник в честь Е.С. Кубряковой / отв. ред. Н.К. Рябцева. Москва : Языки славянских культур, 2009. C. 27-37.

7 Копосов Н.Е. Замкнутая вселенная символов: к истории лингвистической парадигмы. Сочиологический журнал. 1997.№ 4. URL: http://www.socjournal.ru/ article/364. 
цілісності семіотичних утворень, формується сама методика творення тексту, визначається його структура, найбільш придатна для зрозумілого й аргументованого викладення думки в нашому трактуванні дослідження й обгрунтування процесу сновидінь.

Літературознавчий, власне, як і мовний, аспект розкриття сутності оніричної парадигми зводиться до концептуальної цілісності окремих елементів i розглядається через призму їх парадигматичної взаємопов'язаності.

Дослідження підтверджує неоднозначність трактування дефініції «парадигма» в сучасному літературознавстві. Так, Т. Кун зробив вагомий внесок у зміну наукового спрямування досліджень як у галузі філософії, так і соціології в 60-х рр. минулого століття. Зокрема, у книзі «Тhe Structure of Scientific Revolutions» ${ }^{8}$ Т. Кун подає більше як два десятки обгрунтувань досліджуваного поняття, де передусім окреслено парадигму як «визнані всіма наукові досягнення, які впродовж певного часу дають науковому співтовариству модель постановки проблем і їх розв'язків» ${ }^{9}$. За допомогою парадигми вчений досліджує ті підходи, які обгрунтовують так звану, «нормальну науку», що уможливлює вирішення проблеми науковості чи ненауковості. Формування нормальної науки не визначається іï керованістю й дотриманням певних правил, оскільки правила можуть бути похідними від парадигми, а парадигма може керувати дослідженням і за відсутності правил. Останнє 3 тверджень Т. Кун уважав найновішим і найглибшим ${ }^{10}$.

Західна наукова школа, представниками якої є Л. Екберг А. Еффрат, Х. Куклік, К. Ларсон, Х. Мартінс, Н. Муллінз, Дж. Рекс, Р. Рітцера, Р. Фрідріхс, Т. Юнг, розширила наукову парадигмальну концепцію, тобто дисциплінарну матрицю Т. Куна, зокрема, у соціологічному спрямуванні. Водночас П. Ансарт у межах французької соціології 60-80-х pp. ХХ ст. на основі концепцій О. Конта, А. Токвіля, Е. Дюркгейма, П. Прудона, К. Маркса, М. Вебера та ін. окреслив чотири основні парадигми, зокрема генетичний структуралізм П. Бурдьє, динамічний структуралізм Ж. Баландьє й А. Турена, стратегічний підхід М. Крозье та методологічний індивідуалізм Р. Будона ${ }^{11}$.

${ }^{8}$ Kuhn T.S. The Structure of Scientific Revolutions. 2-nd edn. (First published in 1962). Chicago, IL : Univ. of Chicago Press, 1962. P. 54.

${ }^{9}$ Кун Т.С. Структура научных революций / пер. с англ. И.Э. Налетова. Москва, 1975. C. 17. URL: http://www.psylib.ukrweb.net/books/kunts01/ index.htm.

${ }^{10}$ Kuhn T.S. The Structure of Scientific Revolutions. 2-nd edn. (First published in 1962). Chicago, IL : Univ. of Chicago Press, 1962. P. 54.

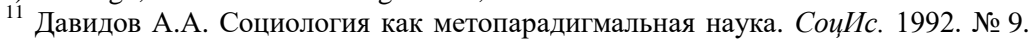
C. $85-87$. 
Розкриття сутнісних особливостей оніричної парадигми в межах сучасного літературознавства безпосередньо стосується антропоцентричних підходів (парадигми), де основним складником художнього твору $є$ людиноцентристська позиція, 3 погляду якої розглядаються світоглядні бачення діючих осіб. Якщо раніше, як наголошує С. Кримський, різні філософські школи надавали фундаментального значення рангам реального або у вигляді матерії як causa sui, або у вигляді реальності за принципом cogito ergo sum (мислю - отже, існую), то нині «на перший план виходить дискурс онтології людини, актуалізується проблема «проміжних» форм реальності, тобто буття, що його засвідчує цивілізація, подаючи його як олюднену дійсність. Це буття локалізоване між двома безоднями нескінченністю космосу та бездонністю людської психіки - утворює особливий «серединний» світ людини» ${ }^{12}$. Аналогічної думки притримується й Л. Шевченко, акцентуючи увагу на гносеологічній теорії пізнання життєвого світу людини, коли вагомого значення набуває «пошук критеріїв цілісного аналізу homo sapiens, виокремлення інтелекту, його природи, складників, функціонування, еволюції й репрезентативних форм як центральної пошукової проблеми, але вже не в диспозиціональній проекції логістичного-чуттєвого, а як єдиної, цілісної, сутнісної характеристики людини» ${ }^{13}$.

Водночас Ф. Бацевич виокремлює антропологічний підхід як один із сучасних аспектів словесної-образності мови, що «розглядається в контексті духовного світу людини» ${ }^{14}$. При цьому сутнісні особливості антропоцентричної парадигми зумовлюються передусім пізнанням людиною світу, власним світосприйняттям «через усвідомлення себе, своєї теоретичної і предметної діяльності в ньому» й, отже, витворює у своїй свідомості «антропоцентричний порядок речей», який, у свою чергу, визначає iï «духовну сутність, мотиви іiі вчинків, ієрархію цінностей» ${ }^{15}$.

Доцільно відмітити, що саме Т. Кун дав поштовх до розширеного розуміння сутності парадигми наукового знання, використовуваної багатогранними науковими школами в багатьох сферах досліджень.

${ }^{12}$ Кримський С.Б. Під сигнатурою Софії. Київ : Вид. дім «Києво-Могилянська академія», 2008. С. 12.

13 Шевченко Л.І. Теоретичні проблеми сучасного мовознавства: пошук дослідницьких парадигм. Слов'янські мови $і$ сучасний світ. Київ : Київський університет, 2000. С. 5-14.

14 Бацевич Ф.С. Нариси 3 комунікативної лінгвістики : монографія. Львів : Видавничий центр ЛНУ ім. Івана Франка, 2003. С. 27.

${ }^{15}$ Маслова В.А. Лингвокультурология : учебное пособие для студ. высш. учеб. заведений. Москва : Издательский центр «Академия», 2001. С. 6-7. 
Узагальнення наукових підходів до трактування цього поняття дає можливість виокремити роль і місце людського фактору, тобто «Я-особи», оскільки через призму його світосприйняття залежить результат обгрунтування концептуальної основи оніричної парадигми в процесі наукового пошуку. Зокрема, у сучасному літературознавстві антропоцентричний підхід відіграє важливу роль, акцентуючи увагу на інтересі до людини як основного концептуального ядра художнього твору, його смислового навантаження.

В. Дем'янков, уживаючи термін «парадигма», закцентовує увагу на людському чиннику теоретичних пояснень і схемі, за якою дослідження здійснюється, протоколюється та інтерпретується ${ }^{16}$. При цьому він зазначає: «Термін «наукова парадигма» за межами наукової метамови починає вживатися більш-менш часто на межі XIX і XX ст. Однак зоряна година його пробила в середині XX століття, коли стало ясно, що від людського чинника не можна відмахнутися навіть у так званих «точних» науках. Причому водночас цей термін одержав нове, «кунівське» значення, що не збігається ні 3 етимологічним, ані 3 тими, які зареєстровані в західноєвропейських $\mathrm{i}$ російській мовах упродовж багатьох сторіч» ${ }^{17}$.

У зазначеному контексті узагальнений характер оніричної парадигми, на нашу думку, відмічається фундаментальністю іï обгрунтування, оскільки досліджуване поняття акумулює загальноприйняті твердження про розглядуваний предмет або явище.

\section{2. Інтердисциплінарний вимір оніричної парадигми}

Зміна сутнісної особливості трактування терміна «онірична парадигма» через інтердисциплінарний вимір потребує логічного доповнення в напрямі певної сфери чи літературознавчого спрямування, оскільки в процесі ії окреслення поняття набуває нового змісту 3 урахуванням характерних особливостей обраної тематики дослідження. У літературознавчій розвідці окреслюється часткова парадигма, яка зводиться до оніричної парадигми в екскурсі мотивів сновидінь.

Поліпарадигмальним аспектом характеризується окремий напрям соціологічної науки - соціологія повсякденного життя, яка повною

16 Демьянков В.3. Парадигма в лингвистике и теории языка. Горизонты современной лингвистики: Традищи и новаторство : сборник в честь Е.С. Кубряковой / отв. ред. Н.К. Рябцева. Москва : Языки славянских культур, 2009. C. 27.

17 Демьянков В.3. Термин парадигма в обыденном языке и в лингвистике. Парадигмы научного знания в современной лингвистике : сборник научных трудов. Москва : ИНИОН РАН, 2006. С. 38. 
мірою є дотичною до оніричного простору. Адже вона вивчає щоденні взаємодії людини, багатогранні пояснювальні моделі виникнення надзвичайних і щоденних ситуацій у суспільному середовищі і процесі життєзабезпечення, тобто як знання про суспільство, де об'єктом дослідження $є$ соціальна реальність і ії основні елементи. Оскільки предметом соціології повсякденного життя, як і багатьох інших наук, $\epsilon$ дослідження явищ і процесів звичного життя, проблем буденного, багатогранні соціологічні дослідження повсякденності й буденності стають ключовою основою літературної розвідки, де осмислення зазначеного може трансформуватися через сновидіння.

Соціологічний підхід в обгрунтуванні парадигми виявляється крізь призму зазначених вище аспектів, оскільки вони дають змогу більш широко розглянути найрізноманітніші сторони життя суспільства, його інтереси, традиції, цінності, звичаї. При цьому соціальне середовище людини під дією економіко-політичних, соціально-духовних і територіально-просторових умов справляють вагомий вплив на формування особистісних людських якостей. Водночас модель соціологічної парадигми повсякденного життя індивідуума є певним прототипом, в якому узагальнюються підходи до реалізації окресленої мети - процесу дослідження оніричної парадигми в художній творчості.

3 метою окреслення оніричної парадигми в межах соціології повсякденного життя застосовуються різноманітні підходи й наукові міждисциплінарні знання, які $\epsilon$ системоутворювальним ядром світобачення i світорозуміння взаємопов'язаних складників. Зазначений процес має перманентний характер, оскільки літературознавча розвідка постійно доповнює й уносить нові підходи та бачення. Так, у процесі формування соціологічних підходів виокремлюють кілька пріоритетних парадигм, що розширюють соціологічні знання. Зокрема, у науковій праці «Структура наукових революцій» Т. Куна зазначається можливість виокремлення таких аспектів парадигми ${ }^{18}$ :

- enicmемічного, де парадигма $\epsilon$ сукупністю фундаментальних знань, цінностей, переконань і технічних прийомів, що слугують зразком для наукової діяльності;

- соціального, де парадигма представлена конкретним науковим співтовариством, цілісність і межі якого вона визначає.

${ }^{18}$ Кун Т. Структура наукових революцій. Київ : Port-Royal, 2001; Кун T.C. Структура научных революций / пер. с англ. И.Э. Налетова. Москва, 1975. URL: http://www.psylib.ukrweb.net/books/kunts01/ index.htm. 
Окремі науковці вважають, що, як у соціології, так й окремому іiі спрямуванні - соціології повсякденного життя, доцільно виділяти три види парадигм ${ }^{19}$ :

- по-перше, ті, які обгрунтовують самостійний статус тієї або іншої науки, відмежовують на якісному рівні одне наукове знання від іншого (філософію від соціології, соціологію від економіки);

- nо-друге, ті, які проводять істотні розбіжності між історичними стадіями в розвитку науки (наприклад, позитивізм, неопозитивізм, постпозитивізм в соціології);

- по-третє, ті, які диференціюють наукову співдружність у рамках однієї й тієї самої науки на тому ж історичному етапі ії розвитку: три парадигми сучасної західноєвропейської соціології.

Парадигмальний статус у соціології повсякденного життя має еволюційний характер, завдяки якому він поетапно трансформується в монопарадигмальний. В інтердисциплінарному контексті зазначений статус проходить різні етапи (за Т. Куном), починаючи 3 допарадигмального до різноманітно-парадигмального статусу ${ }^{20}$. Тобто процес досліджень парадигми соціології повсякденного життя, на відміну від одноваріантного та монопарадигмального статусу, зумовлюється багатоваріантністю й поліпарадигмальністю.

Розвиток інтерпретації соціальної парадигми започатковано М. Вебером, який закцентував увагу на тому, що соціальна реальність розглядається через світосприйняття індивідуумом певної соціальної дії, а роль науковця-соціолога полягає в осягненні реальних мотивів розуміння особою зазначеної дії ${ }^{21}$. Водночас соціальна дія підпорядковується певному соціальному порядку, що має цінніснообгрунтований характер, оскільки будь-який індивідуум або ж члени суспільства загалом дотримуються соціального порядку в межах соціального середовища й у процесі суспільного розвитку.

У подальшому еволюційний розвиток тлумачення соціології повсякденного життя призвів до формування наукових підходів і напрямів, зокрема феноменологічної соціології А. Шюца, етнометодології Г. Гарфінкля, символічного інтеракціонізму Т. Лукмана i Дж. Міда ${ }^{22}$. Зазначені підходи зумовлюються соціальною парадигмою,

${ }^{19}$ Осипов Г.В., Москвичев Л.Н. Социология: основы общей теории. Москва : Норма, 2002. 889 с.

${ }^{20}$ Кун Т.С. Структура научных революций / пер. с англ. И.Э. Налетова. Москва, 1975. C. 71. URL: http://www.psylib.ukrweb.net/books/kunts01/ index.htm.

21 Вебер М. Три чисті типи легітимного панування. Соиіологія. Загальноісторичні аналізи. Політика. Київ : Основи, 1998. С. 157-172.

22 Социологические парадигмы / Ю.Г. Волков, В.И. Добреньков, В.Н. Нечипуренко, А.В. Попов. Социология. Москва : Гардарики, 2004. С. 66. 
де процес соціальної дії та соціального розвитку супроводжується безперервністю взаємодії індивідуума й суспільства в межах соціумі, що є своєрідним соціальним феноменом, який об'єднує множинність індивідуальних дій.

У процесі дослідження виявлено, що ключовими поняттями до обгрунтування парадигми соціології повсякденного життя є:

- суспільство як цілісна соціальна система, де формуються своєрідні соціальні відносини, відбувається взаємозв'язок і комунікація між індивідуумами й окремими спільнотами в процесі суспільного розвитку;

- особа (у соціологічному розумінні) як розумна істота, яка соціально адаптована, має неповторну індивідуальність, свідомовольові якості та власну позицію щодо співіснування в суспільному середовищі;

- соціальна поведінка як поведінка індивідуума, що розкривається у співіснуванні та взаємодії із соціальними групами, формуючись під впливом відповідного еволюційного етапу суспільного розвитку, окреслюючи риси особистості в процесі їі соціалізації;

- соціальні групи як сукупність індивідуумів, об'єднаних соціальними критеріями. Зазначені групи є зв'язувальним складником між окремою особою та суспільством загалом;

- соціальні інститути як еволюційно сформовані функціональні взаємодії в межах соціальної системи, які володіють можливістю до самовідтворення, задовольняючи при цьому життєво необхідні потреби членів суспільства;

- соціальні організації як сформовані соціальні групи, в основі яких виокремлено певні норми поведінки й окреслено соціальний порядок їх дотримання з метою досягнення результативних цілей;

- соиіальні факти, які розглядаються як результат поведінки індивідів, передусім через їхню діяльність у межах соціуму, де соціальне середовище, так зване «соціальне мільйо» як складник середовища існування людини, справляє значний вплив на формування особистості.

Дослідження узагальнених вище категорій, що застосовуються при розкритті сутності парадигми соціології повсякденного життя, простежуються в доробку багатьох літературознавців. Так, окремі науковці, розглядаючи соціальну поведінку індивідууму, акцентують увагу на ціннісному аспекті діяльності людини, іiі індивідуальних здібностях і навичках, які проявляються в поведінковій адаптації до співіснування із соціальним середовищем у процесі суспільного 
розвитку ${ }^{23}$. Водночас функціональність концепції соціальної поведінки Ч. Анкович і Дж. Келуджер зводять до спроб індивіда задовольнити власні соціальні потреби ${ }^{24}$. Однак, як уважають Д. Сток і Х. Селен, кожний індивід володіє значною кількістю потенційних можливостей, які реалізовуються відповідно до певної ситуації, i, як правило, залежать від належності культури групи внутрішній культурі індивіда ${ }^{25}$.

Через соціальну взаємодію та формування певної рівноваги між соціальним та індивідуальним Т. Парсонс розглядає багатогранність типів поведінки і спрямованість соціальної дії як із погляду інституціоналізації дії, що зумовлюється виокремленням соціальних норм i формуванням правил поведінки індивідууму згідно із суспільним потребам, так і з погляду соціалізації особистості, що $\epsilon$ результатом системного процесу розширеного відтворення духовнокультурних цінностей суспільства ${ }^{26}$.

Правила поведінки індивідуума визначаються соціальними інститутами. Уперше сутність зазначеного поняття сформульовано Г. Спенсером, який у подальшому окреслив основні соціальні інститути, зокрема сімейний, обрядовий, політичний, релігійний та економічний. При цьому вчений акцентував увагу на тому, що соціальні інститути («інституції») є певними складниками каркаса соціуму й виникають у результаті процесу диференціації суспільства, поєднуючи розвиток соціальних інститутів з розвитком регулятивної системи суспільства ${ }^{27}$.

Літературознавча розвідка в напрямі обгрунтування парадигми соціології повсякденного життя стосується й розкриття поняття соціальних організацій, оскільки людина $є$ найважливішим елементом соціальної системи, а організація, у свою чергу, - складником суспільства. При цьому організація, при всій своїй унікальності має колективну дію, універсальність теоретичних підходів якої на основі нормативістської критики раціональної моделі дії обгрунтував

${ }^{23}$ Анисимов С.Ф. Мораль и поведение. Москва : Наука, 1985. С. 16; Головко Н.А., Буева Л.П., Шердаков В.Н. Мораль: сознание и поведение. Москва : Наука, 1986. С. 24; Волченко Е.Б. Гуманность, деликатность, вежливость и этикет. Москва : Изд-во Моск. ун-та, 1995. С. 81.

24 Kaluger G., Unkovik Ch. Psychology and sociology: an integrated approach to human behavior. Saint Luis : Mosby, 1969. P. 19.

${ }^{25}$ Stock D., Thelen H. Emotional dynamics and group culture. Washington, 1958. P. 9, 33 .

${ }^{26}$ Parsons T. The Social System. Glencor III, 1957. P. 89.

${ }^{27}$ Спенсер Г. Основания социологии : в 2 т. / пер. с англ. Санкт-Петербург : Изд. И.И. Билибина, 1876. Т. ІІ. С. 94. 
Н. Смелзер ${ }^{28}$. Вагомими є також наукові напрацювання Е. Хоффера в плані обгрунтування соціальної природи організацій і розширення мережі соціальних рухів у межах соціальної системи ${ }^{29}$.

Наукові дослідження М. Вебера, утілені в роботі «Основні соціологічні поняття», розкривають сутність соціальної поведінки людей у межах соціальних утворень (держави, асоціацій, акціонерних товариств, установ тощо), тобто «процесів і зв'язків специфічної поведінки окремих людей, тому що тільки вони виявляють собою зрозумілих для нас носіїв осмислених дій» ${ }^{30}$.

Узагальнення наукових підходів до розкриття сутності парадигми соціології повсякденного життя у сфері літературознавства дає можливість сформувати власне бачення змістового наповнення зазначеного поняття, яке взаємозумовлюється передумовами суспільного життя, певною соціальною реальністю з їі багатогранними елементами, закономірними явищами та процесами й із окресленням місця та ролі індивідуума в суспільстві. При цьому формується системоутворювальне ядро взаємодії індивідуума із суспільством у межах соціального середовища на основі поєднання ціннісних і духовних інтересів, світобачення і світорозуміння для реалізації спільної мети.

Сутність оніричної парадигми в психології, що розглядається через призму детермінізму, полягає у виявленні взаємозалежностей і взаємозв'язків між явищами та процесами, окремими елементами й речами. Зокрема, поняття детермінізму (лат. determinatus «визначений», «обмежений») трактується як учення про всезагальну причинну зумовленість, закономірний зв'язок усіх явищ у природі, суспільстві й мисленні, тобто взаємозумовленості явищ, де одне явище (причина) при відповідних умовах спонукає інше (дію).

Наукове розуміння детермінізму застерігає літературознавця від прямолінійного трактування співвідношення життя й літератури (за схемою «базис визначає надбудову»), літературного чи історичного процесів. Детермінізм конкретизується в традиційному літературознавстві при обговоренні проблем «обставини й характери», «мотивація вчинків персонажа», «впливи та взаємовпливи в літературі» ${ }^{31}$. Загалом детермінізм у сфері літературознавства

${ }^{28}$ Smelser N.J. Problematics of Sociology: the George Simmel lectures, 1995. Berkeley, Los Angeles: Univ.of California Press, 1997. 115 p.

${ }^{29}$ Hopper E. Stratification, Education and Mobility in Industrial Societies. Readings in the Theory of Educational Systems / ed. by E. Hopper. London : Hutchinson, 1971. P. 71-90.

${ }^{30}$ Вебер М. Избранные произведения. Москва : Прогресс, 1990. 805 с.

31 Літературознавчий словник-довідник / Р.Т. Гром'як, Ю.І. Ковалів та ін. Київ : ВЦ «Академія», 1997. С. 193. 
охоплює взаємозумовленість окремих процесів, природних явищ, світоглядних аспектів людського буття, тісно пов'язаних із людською свідомістю, полісемічністю художніх образів, причинною наслідковістю, зрештою, у взаємозв'язку та взаємозалежності явищ і процесів, які відбуваються під впливом зовнішніх i внутрішніх факторів у підсвідомості людини.

Парадигмальний підхід у розкритті оніричних елементів тісно пов’язаний із концепцією психоаналізу 3. Фройда, згідно 3 якою внутрішнє життя будь-якого індивіда визначається змістом несвідомого рівня його психіки. При цьому соціальна реальність розглядається як продукт боротьби, яка не припиняється, індивідуального (інстинктивного) початку і гнітючого його суспільства. Саме боротьба була ключовим моментом у формуванні культури, мистецтва, вчинків і дій індивідів, виникненні й досягненні успіху різних ідеологій, спрямованості політики держав.

Отже, дослідження підтверджує, що оніричну парадигму доцільно розглядати через призму інтердисциплінарного виміру, оскільки іï поглиблене вивчення стосується як соціологічної сфери повсякденного життя, так і психоаналітичних і філософських підходів, що застосовуються в процесі наукової розвідки життєвого середовища людини, причинно-наслідкових зв'язків ऑї діяльності. Парадигма соціології повсякденного життя співпадає із сутнісними особливостями оніричної парадигми, оскільки реалії життєвого середовища індивідуума взаємозумовлюються із соціальним середовищем i в подальшому переосмислюються людиною. Зазвичай вони проявляються в сновидіннях передусім через фантазії й ілюзії у вигляді нереалізованих бажань, мрій і прагнень. Це ж стосується сфери літературознавства й досліджень, спрямованих на вивчення оніричного простору, а також процесу узагальнення художніх образів, створених творчою уявою митця під впливом внутрішніх і зовнішніх чинників середовища існування людини.

\section{ВИСНОВКИ}

Узагальнення теоретичних підходів до трактування поняття «онірична парадигма» дало можливість сформулювати власне бачення зазначеної дефініції. Розуміння сутності оніричної парадигми як особливого підходу до наукових літературознавчих досліджень зумовлюється виокремленням узагальненої моделі, зразку або ж прикладу сукупності оніричних елементів, які застосовуються в процесі художнього творення, окреслюючи спрямованість наукової розвідки, їі концептуальної основи 3 метою формування певної програми або алгоритму розв'язання обраної дослідницької тематики. Ідеться про своєрідний, оригінальний взірець або 
ж еталон, якому притаманна першооснова, самодостатність і нестандартність твердження літературознавчого пошуку в процесі дослідження оніричної парадигми.

Дослідженням виявлено, що онірична парадигма корелює 3 певними «правилами гри» в межах інтердисциплінарного виміру з окресленням наукових підходів до тематики. В інтердисциплінарному вимірі поряд 3 окресленням оніричного аспекту часто застосовують поняття наукової парадигми як своєрідного формування сукупності наукової думки, специфічної філософської теорії, яка $\epsilon$ певним взірцем або ж загальновживаною моделлю в науковому світі, де окреслюється антропологічний аспект 3 урахуванням соціально-психологічних чинників суспільного середовища, зокрема, і в літературознавчій сфері. Зазначена парадигма має теоретичне підгрунтя, яке формулюється через призму людського бачення і $є$ певною образно-пояснювальною схематичною розробкою для проведення літературознавчої розвідки. Парадигма як універсальна концептуальна основа зводиться до міждисциплінарної схематичної розробки із сутнісним розумінням причинно-наслідкових зв'язків у розкритті сюжетної лінії художнього твору, яка в контексті дослідження може розглядатися в різних природничо-гуманітарних сферах, зокрема філософії, соціології, психології й літературознавстві. Крім цього, узагальнене трактування наукової парадигми придатне як для лінгвістичного, так i до літературознавчого пошуку.

Онірична парадигма характеризується взаємозумовленістю психологічного детермінізму, сформованого на основі соціальнопсихологічного підходу до дослідження особистісних властивостей людини, ii комунікативно-психологічних можливостей, зокрема потенційних здібностей і творчих якостей індивіда, які використовуються в процесі спілкування з окремими людьми й соціальною групою.

\section{АНОТАЦІЯ}

У статті узагальнено науково-теоретичні підходи до трактування оніричної парадигми, зокрема, в інтердисциплінарному вимірі. Результати дослідження стосуються окреслення сутнісного складника оніричної парадигми, яка зводиться до формування узагальненої моделі 3 проекцією на сукупність оніричних елементів, що застосовуються в процесі створення художнього твору. Обгрунтовано, що зазначена модель зумовлюється своєрідним, оригінальним взірцем або ж еталоном, якому притаманна першооснова, самодостатність і нестандартність твердження літературознавчого пошуку.

Дослідженням виявлено, що онірична парадигма зумовлюється певними «правилами гри» в межах інтердисциплінарного виміру 
3 окресленням наукових підходів до тематики. Водночас підтверджено, що онірична парадигма відмічається взаємозумовленістю психологічного детермінізму, сформованого на основі соціальнопсихологічного підходу до дослідження особистісних властивостей людини, іiї комунікативно-психологічних можливостей.

\section{ЛIТЕРАТУРА}

1. Анисимов С.Ф. Мораль и поведение. Москва : Наука, 1985. $285 \mathrm{c}$.

2. Головко Н.А., Буева Л.П., Шердаков В.Н. Мораль: сознание и поведение. Москва : Наука, 1986. 208 с.

3. Волченко Е.Б. Гуманность, деликатность, вежливость и этикет. Москва : Изд-во Моск. ун-та, 1995. 115 с.

4. Бацевич Ф.С. Нариси з комунікативної лінгвістики : монографія. Львів : Видавничий центр ЛНУ ім. Івана Франка, 2003. 281 с.

5. Вебер М. Избранные произведения. Москва : Прогресс, 1990. $805 \mathrm{c}$.

6. Вебер М. Три чисті типи легітимного панування. Соціологія. Загальноісторичні аналізи. Політика. Київ : Основи, 1998. С. 157-172.

7. Социологические парадигмы / Ю.Г. Волков, В.И. Добреньков, В.Н. Нечипуренко, А.В. Попов. Социология. Москва : Гардарики, 2004. $511 \mathrm{c}$.

8. Гиршман М.М. Литературное произведение: теория и практика анализа : учебное пособие. Москва : Высш. шк., 1991. 160 с.

9. Давидов А.А. Социология как метопарадигмальная наука. СоиИс. 1992. № 9. С. 85-87.

10. Демьянков В.3. Парадигма в лингвистике и теории языка. Горизонты современной лингвистики: Традиции и новаторство : сборник в честь Е.С. Кубряковой / отв. ред. Н.К. Рябцева. Москва : Языки славянских культур, 2009. С. 27-37.

11. Демьянков В.3. Термин парадигма в обыденном языке и в лингвистике. Парадигмы научного знания в современной лингвистике : сборник научных трудов. Москва : ИНИОН РАН, 2006. С. 15-40.

12. Копосов Н.Е. Замкнутая вселенная символов: к истории лингвистической парадигмы. Социологический журнал. 1997. № 4. URL: http://www.socjournal.ru/article/364.

13. Кримський С.Б. Під сигнатурою Софії. Київ : Вид. дім «КиєвоМогилянська академія», 2008. 367 с.

14. Кун Т.С. Структура научных революций / пер. с англ. И.Э. Налетова. Москва, 1975. URL: http://www.psylib.ukrweb.net/ books/ kunts01/ index.htm.

15. Кун Т. Структура наукових революцій. Київ : Port-Royal, 2001. $228 \mathrm{c}$. 
16. Кун Т.С. Структура научных революций / пер. с англ. И.Э. Налетова. Москва, 1975. URL: http://www.psylib.ukrweb.net/ books/kunts01/ index.htm.

17. Маслова В.А. Лингвокультурология : учебное пособие для студ. высш. учеб. заведений. Москва : Издательский центр Академия, 2001. $208 \mathrm{c}$.

18. Осипов Г.В., Москвичев Л.Н. Социология: основы общей теории. Москва : Норма, 2002. 889 с.

19. Спенсер Г. Основания социологии : в 2 т. / пер. с англ. СанктПетербург : Изд. И.И. Билибина, 1876. Т. II. 897 с.

20. Шевченко Л.І. Теоретичні проблеми сучасного мовознавства: пошук дослідницьких парадигм. Слов'янські мови і сучасний світ. Київ : Київський університет, 2000. С. 5-14.

21. DIYanni R. Literature: Reading Fiction, Poetry, Drama, and the Essay. $4^{\text {th }}$ ed. McGraw-Hill, 1998. P. 40-102.

22. Gordon J.B., Kuehner K. Fiction: the Elements of the Short Story. McGraw-Hill Glencoe, 2000. 456 p.

23. Hevner A.R., March S.T., Park J., Ram S. Design Science in Information Systems Research. MIS Quarterly. 2004. № 28. P. 75-105.

24. March S.T., Smith G.F. Design and Natural Science Research on Information Technology. Decision Support Systems. 1995. № 15. P. 251-266.

25. Hirschheim R., Klein H.K. Four Paradigms of Information Systems Development. Communications of the ACM. 1989. № 32. P. 1199-1216.

26. Hopper E. Stratification, Education and Mobility in Industrial Societies. Readings in the Theory of Educational Systems / ed. by E. Hopper. London: Hutchinson, 1971. P. 71-90.

27. Kaluger G., Unkovik Ch. Psychology and sociology: an integrated approach to human behavior. Saint Luis : Mosby, 1969. 404 p.

28. Kuhn T.S. The Structure of Scientific Revolutions. Chicago, IL : Univ. of Chicago Press, 1962. 210 p.

29. Parsons T. The Social System. Glencor III, 1957. 314 p.

30. Smelser N.J. Problematics of Sociology: the George Simmel lectures, 1995. Berkeley, Los Angeles : Univ.of California Press, 1997. 115 p.

31. Stock D., Thelen H. Emotional dynamics and group culture. Washington, 1958. $213 \mathrm{p}$.

\section{Information about the author: \\ Hazuda O. M.,}

Graduate Student at the Department of Theory and Practice of Translation

Uzhhorod National University 14, Universytetska str., Uzhhorod, 88000, Ukraine 